\title{
Simulation study to find suitable dopants of CdS buffer layer for CZTS solar cell
}

\author{
Farjana Akter Jhuma ${ }^{1}$ Mohammad Junaebur Rashid ${ }^{1,2}$
}

Received: 6 July 2019 / Accepted: 18 December 2019 / Published online: 27 December 2019

(c) The Author(s) 2020

\begin{abstract}
The performance of CZTS solar cell, a promising candidate in the field of energy production from sunlight, can be improved by optimizing the parameters of most widely used CdS buffer layer. In this work, numerical study have been done on the typical CZTS solar cell structures containing Mo thin film as back contact on glass substrate using SCAPS-1D solar cell simulation software. Then, the CZTS has been used as the absorber layer followed by CdS buffer later. Following, $\mathrm{ZnO}$ and transparent conducting oxide n-ITO layers have been considered as window layer and front contact, respectively. In the simulations, the CdS buffer layer has been doped with three different materials such as Silver (Ag), Copper (Cu) and Chlorine (Cl) for a wide acceptable range of carrier concentration. After obtaining the suitable carrier concentration, the thickness of the doped buffer layer has been varied keeping other layer parameters constant to see the variation of performance parameters open circuit voltage $\left(V_{\mathrm{oc}}\right)$, short circuit current density $\left(J_{\mathrm{sc}}\right)$, fill factor (FF) and efficiency $(\eta)$ of the CZTS solar cell.
\end{abstract}

Keywords CZTS $\cdot$ Doped CdS $\cdot$ Solar cell $\cdot$ SCAPS-1D $\cdot$ Carrier concentration

\section{Introduction}

The green and clean solar energy source has a high potential and reliable form of power for electricity generation as the solar energy can be directly converted into electricity using the photovoltaic principles. For obtaining cost-effective and highly efficient photovoltaic solar cell, different materials like $\mathrm{Si}, \mathrm{CdTe}, \mathrm{Cu}(\mathrm{In}, \mathrm{Ga}) \mathrm{Se}_{2}$ (CIGS), $\mathrm{Cu}_{2} \mathrm{ZnSnS}_{4}$ (CZTS), CZTSSe and organic materials have been considered by many researchers as an absorber layer for the fabrication of solar cell [1-3]. Si is the most widely used absorber material which suffers from low throughput and high cost though up to $24.5 \%$ efficiency can be achieved using it $[4,5]$. Up to $21 \%$ and $21.7 \%$ efficiency have been achieved for second generation CdTe and CIGS solar cell [6]. But due to the toxicity of cadmium and selenium, and less availability

Farjana Akter Jhuma

jhuma.univdhaka@gmail.com

Mohammad Junaebur Rashid

mjrashid@du.ac.bd

1 Semiconductor Technology Research Centre, Faculty of Science, University of Dhaka, Dhaka 1000, Bangladesh

2 Department of Electrical and Electronic Engineering, University of Dhaka, Dhaka 1000, Bangladesh of tellurium and indium, an alternative material CZTS has achieved great attraction among the researchers during last couple of years $[7,8]$.

CZTS is a quaternary semiconductor with non-toxic earth abundant constituent material. It exhibits excellent photovoltaic properties such as absorption coefficient above $10^{4} \mathrm{~cm}^{-1}$ and direct bandgap of 1.4-1.6 eV [9, 10]. The maximum reported efficiency of CZTS solar cell is $\sim 11 \%$ [11]. For CZTS solar cell, researchers are using different buffer layers such as CdS, ZnS and CdZnS [12]. Among them CdS turned out as a most potential buffer layer for CZTS solar cell, even though it has toxic component and wastage probability [13].

Cadmium sulfide (CdS), a naturally grown n-type semiconductor is an important inorganic chemical compound in II-VI semiconductor family with excellent structural, optical and electrical properties [14-16]. The energy bandgap of CdS $2.42 \mathrm{eV}$ allows maximum absorption of photons in the absorber layer [17]. For achieving enhanced performance of the CZTS solar cell, the thickness of the CdS buffer layer should be kept around $50 \mathrm{~nm}$ to reduce the absorption loss in the buffer layer [12]. For getting a more efficient buffer layer, the resistivity of CdS layer needs to be reduced which can be achieved through doping with different materials such as Silver (Ag), Copper (Cu), Chlorine (Cl), Indium (In), Aluminum $(\mathrm{Al})$ and others [18-22]. The electrical, optical and 


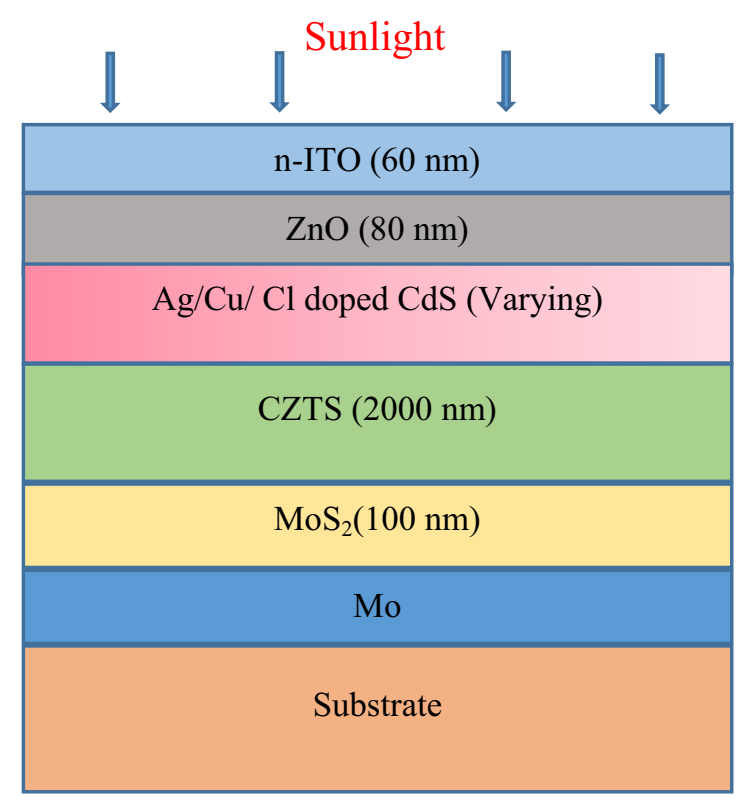

Fig. 1 Schematic structure of CZTS thin film solar cell

structural properties of CdS are extremely delicate to the presence of these impurities and can be controlled by the amount of doping. In this simulation process, Silver (Ag), Copper $(\mathrm{Cu})$ and $\mathrm{Chlorine}(\mathrm{Cl})$ have been considered as the dopant materials for CdS buffer layer for achieving high efficiency CZTS solar cell. To observe the effect of these dopants into the performance of the devices and to optimize the solar cell structure, numerical simulation seems to be an effective way.

In this work, numerical simulations based on SCAPS1D solar cell modelling tool have been used to observe the effect of variation in carrier concentration and thickness of doped CdS buffer layer into the performance of the CZTS solar cell. Solar cell performance parameters such as open circuit voltage $\left(V_{\mathrm{oc}}\right)$, short circuit current density $\left(J_{\mathrm{sc}}\right)$, fill factor (FF) and efficiency $(\eta)$ have been calculated and performance analysis have been done for $\mathrm{Cu}-, \mathrm{Cl}$ - and $\mathrm{Ag}$-doped CdS/CZTS solar cell structures.

\section{Device structure and methodology}

\section{Device structure}

Figure 1 displays the solar cell structure used in this study. The structure starts with soda lime glass layer that has been used as the substrate material. A thin $\mathrm{MoS}_{2}$ layer with a thickness of $100 \mathrm{~nm}$ is used as it can be formed during experiment by the reaction of Mo back contact with sulfur contained in the CZTS layer of the solar cell [23]. The next layer is $2000 \mathrm{~nm}$ thick CZTS absorber layer which has been used to absorb most of the incident photons to produce electron-hole pairs. Doped CdS buffer layer has been used after the absorber layer to provide the band alignment with the CZTS absorber. Subsequently, as a window layer $80 \mathrm{~nm}$ thick Zinc Oxide ( $\mathrm{ZnO})$ which is less expensive and easily available, has been used to improve the light scattering. It basically enables the efficient use of sun light by maximizing the no of incident photons to the buffer and absorber layers [24]. Lastly, a transparent conducting film n-type Indium doped Tin Oxide (n-ITO) has been used with a thickness of $60 \mathrm{~nm}$ for increasing the carrier mobility via increased visible absorption to obtain a lower sheet resistance [25].

Table 1 The physical parameters of different layer

\begin{tabular}{|c|c|c|c|c|c|c|c|}
\hline Parameter & $\mathrm{MoS}_{2}$ & CZTS & Ag-doped CdS & Cu-doped CdS & Cl-doped CdS & $\mathrm{ZnO}$ & n-ITO \\
\hline Thickness (nm) & 100 & 2000 & Varying & Varying & Varying & 80 & 60 \\
\hline Band gap (eV) & 1.7 & 1.5 & 2.42 & 2.42 & 2.42 & 3.3 & 3.6 \\
\hline Electron affinity (eV) & 4.2 & 4.5 & 4.5 & 4.5 & 4.5 & 4.6 & 4.1 \\
\hline Dielectric permittivity & 13.6 & 10 & 10 & 10 & 10 & 9 & 10 \\
\hline CB effective density of states $\left(\mathrm{cm}^{-3}\right)$ & $2.2 \times 10^{18}$ & $2.2 \times 10^{18}$ & $2.2 \times 10^{18}$ & $2.2 \times 10^{18}$ & $2.2 \times 10^{18}$ & $2.2 \times 10^{18}$ & $2.2 \times 10^{18}$ \\
\hline VB effective density of states $\left(\mathrm{cm}^{-3}\right)$ & $1.8 \times 10^{19}$ & $1.8 \times 10^{19}$ & $1.8 \times 10^{19}$ & $1.8 \times 10^{19}$ & $1.8 \times 10^{19}$ & $1.8 \times 10^{19}$ & $1.8 \times 10^{19}$ \\
\hline Electron thermal velocity $\left(\mathrm{cms}^{-1}\right)$ & $1 \times 10^{7}$ & $1 \times 10^{7}$ & $1 \times 10^{7}$ & $1 \times 10^{7}$ & $1 \times 10^{7}$ & $1 \times 10^{7}$ & $1 \times 10^{7}$ \\
\hline Hole thermal velocity $\left(\mathrm{cm}^{-1}\right)$ & $1 \times 10^{7}$ & $1 \times 10^{7}$ & $1 \times 10^{7}$ & $1 \times 10^{7}$ & $1 \times 10^{7}$ & $1 \times 10^{7}$ & $1 \times 10^{7}$ \\
\hline Electron mobility $\left(\mathrm{cm}^{2} / \mathrm{V}_{\mathrm{s}}\right)$ & 100 & 100 & 100 & 100 & 100 & 100 & 50 \\
\hline Hole mobility $\left(\mathrm{cm}^{2} / V_{\mathrm{s}}\right)$ & 25 & 25 & 25 & 25 & 25 & 25 & 75 \\
\hline Shallow uniform donor density, $N_{\mathrm{D}}\left(\mathrm{cm}^{-3}\right)$ & 0 & $1 \times 10^{1}$ & Varying & Varying & Varying & $1 \times 10^{18}$ & $1 \times 10^{19}$ \\
\hline Shallow uniform acceptor density, $N_{\mathrm{A}}\left(\mathrm{cm}^{-3}\right)$ & $1 \times 10^{16}$ & $2 \times 10^{14}$ & 0 & 0 & 0 & 0 & 0 \\
\hline Defect type & - & Donor & Acceptor & Acceptor & Acceptor & - & - \\
\hline Defect density, $\left(\mathrm{cm}^{-3}\right)$ & & $1 \times 10^{13}$ & $6 \times 10^{16}$ & $6 \times 10^{16}$ & $6 \times 10^{16}$ & & \\
\hline
\end{tabular}




\section{Numerical simulation and material parameters}

SCAPS-1D has been used for numerically evaluating the solar cell performance. The software is a one dimensional solar cell simulation software which was developed at the department of Electronics \&Information Systems (EIS), University of Gent, Belgium, where up to seven different layers can be added in the cell definition panel of the software which makes it more efficient for solar cell simulation. Physical properties such as band gap, electron affinity, dielectric permittivity, electron and hole mobility, etc., for different layers can be adjusted in the layer properties panel for achieving the desired structure. The working point environment can be specified in the action panel. A large number parameters such as short circuit current density $\left(J_{\mathrm{sc}}\right)$, open circuit voltage $\left(V_{\mathrm{oc}}\right)$, fill factor $(\mathrm{FF})$, conversion efficiency $(\eta)$ and other performance parameters can be calculated as well as displayed using the software SCAPS-1D [26].

The illumination of light has been from the right contact with "Air mass 1.5 global" spectrum with a light power of one sun $\left(1000 \mathrm{~W} / \mathrm{m}^{2}\right)$ at working temperature of $300 \mathrm{~K}$. Two types of single layer defect were introduced in the absorber layer and buffer layer for the simulations. The values of the physical parameters used in this study have been all taken from experimental study, different studies or reasonable estimates which have been summarized in Table 1 [27-30].

The simulations have been done in two steps: first by varying carrier concentration of the doped $\mathrm{CdS}$ buffer layer and then by varying the thickness of the doped CdS buffer using the optimized carrier concentration. At the time of each simulation, the solar cell performance parameters $V_{\mathrm{oc}}, J_{\mathrm{sc}}, \mathrm{FF}$ and $\eta$ have been calculated and plotted against carrier concentration and buffer thickness. During each simulation, the thickness and the physical properties of the other layer have been kept fixed.

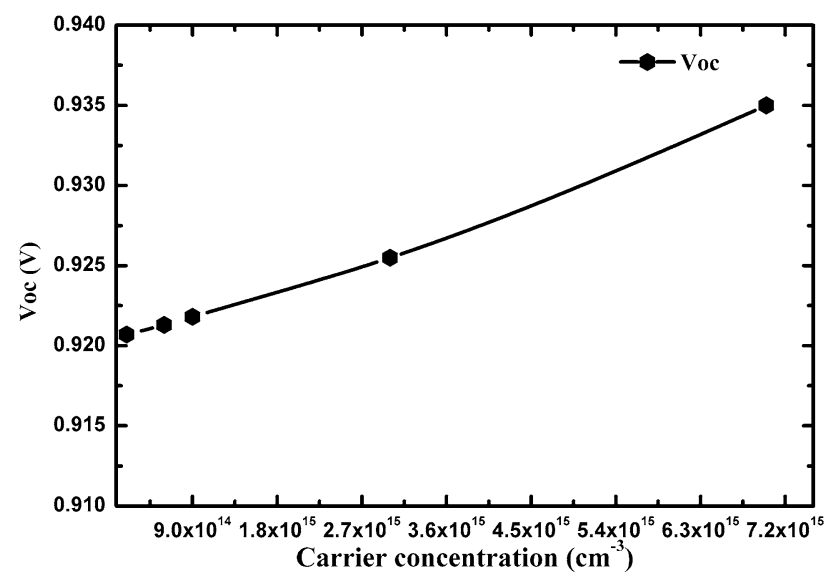

(a)

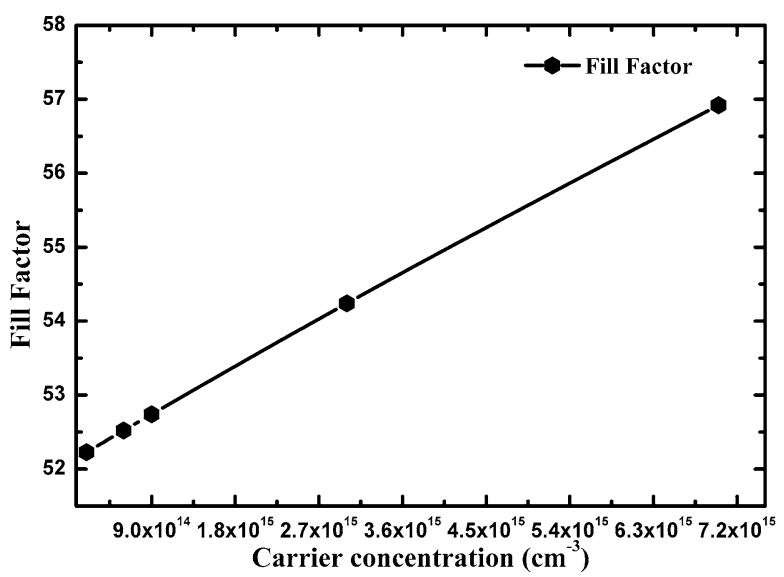

(c)

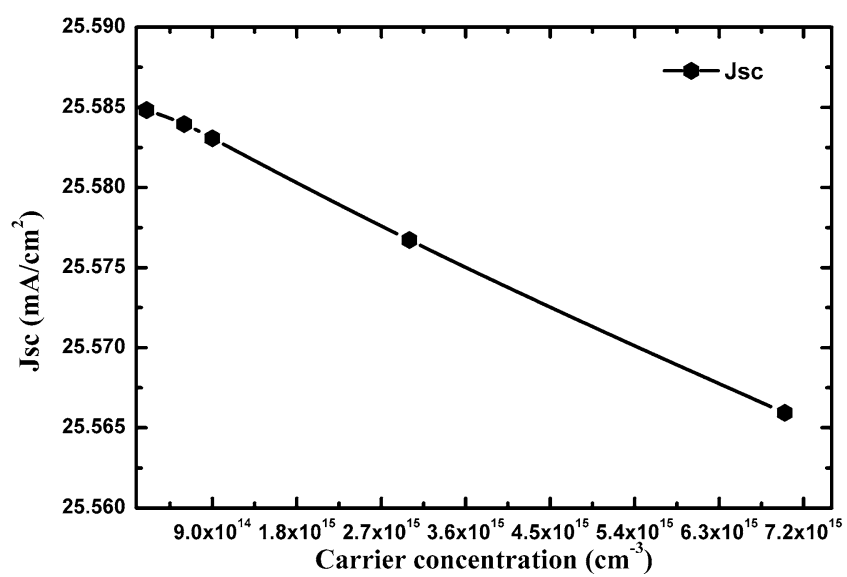

(b)

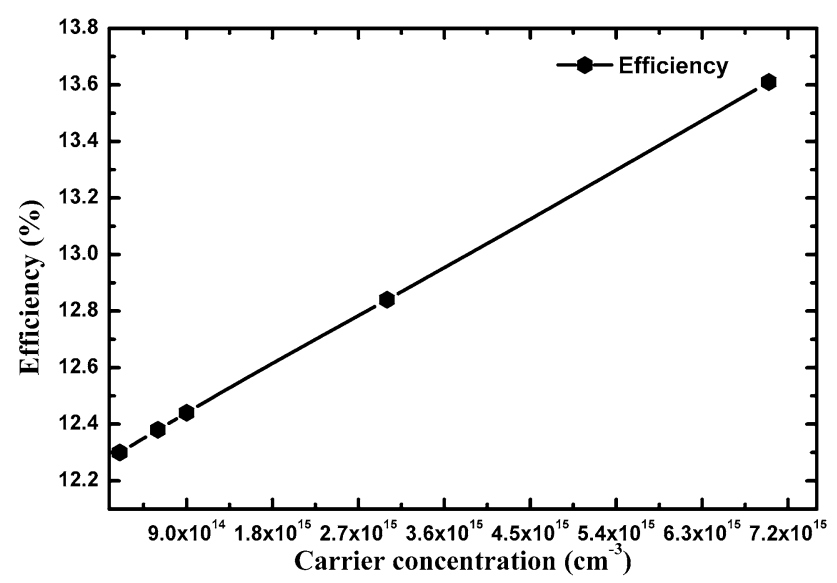

(d)

Fig. 2 Effect of carrier concentration of Ag-doped CdS layer on $\mathbf{a} V_{\mathrm{oc}}, \mathbf{b} J_{\mathrm{sc}}, \mathbf{c}$ fill factor, $\mathbf{d}$ efficiency 


\section{Results and discussion}

\section{Effect of carrier concentration of doped CdS buffer layer}

To study the effect of carrier concentration of doped CdS buffer on solar cell, simulations have been done on the structure shown in Fig. 1 with three different dopants such as Silver (Ag), Copper $(\mathrm{Cu})$ and Chlorine $(\mathrm{Cl})$ in $\mathrm{CdS}$ layer. In the case of $\mathrm{Ag}$ and $\mathrm{Cu}$ dopants, at lower doping both $\mathrm{Ag}^{+}$and $\mathrm{Cu}^{+}$ion can substitutionally replace the $\mathrm{Cd}^{+}$ion resulting in lower carrier concentration. But with increased amount of doping, a great number of $\mathrm{Ag}$ atoms or $\mathrm{Cu}$ atoms start to occupy the interstitial site of the CdS lattice increasing the value of carrier concentration [18, 31]. However, in the case of $\mathrm{Cl}$, the scenario is somehow different. As chlorine forms an anion, it substitutes the Sulfur ion of CdS instead of the Cadmium ion substitutionally. At higher

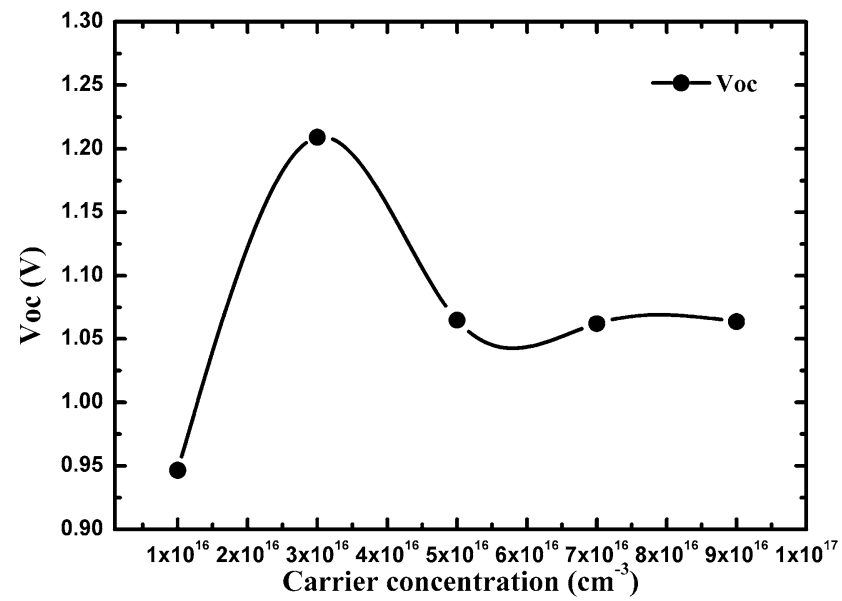

(a)

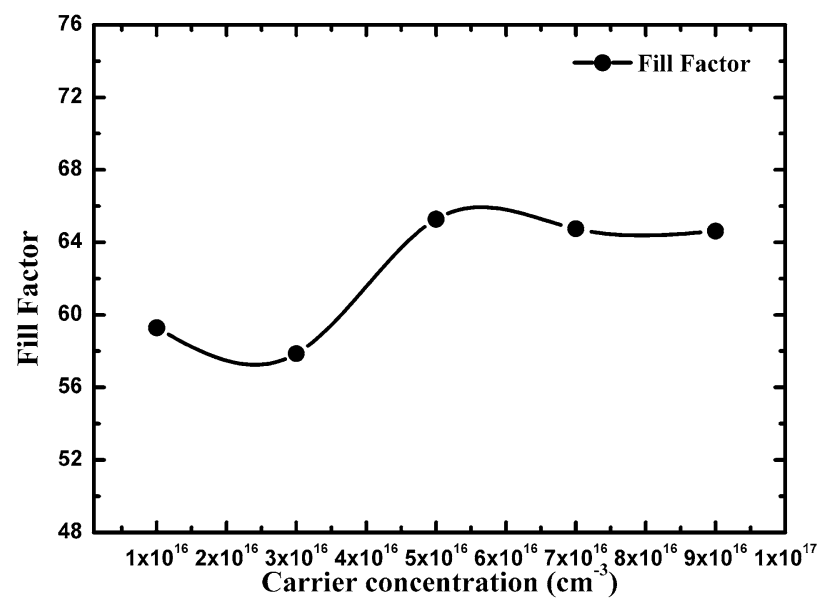

(c) doping concentration, there is annihilation of acceptor and donor center in $\mathrm{CdS}$ to incorporate $\mathrm{Cl}$ atoms leads to higher carrier concentration [32]. In this work, first the simulations have been done for Ag-doped CdS/CZTS structure. The carrier concentration has been changed from $2 \times 10^{14}$ to $7 \times 10^{15} \mathrm{~cm}^{-3}$ which is within the experimentally found values [18]. The variations of different solar cell parameters for Ag-doped CdS have been presented in Fig. 2 with respect to carrier concentration. The second set of simulations has been carried out for $\mathrm{Cu}$-doped CdS/CZTS structure. The carrier concentration varied from $1 \times 10^{16}$ to $9 \times 10^{16} \mathrm{~cm}^{-3}$ which has been also found experimentally for $\mathrm{Cu}$-doped $\mathrm{CdS}$ thin layer [19]. The variation of solar cell parameters for different carrier concentration for $\mathrm{Cu}$-doped $\mathrm{CdS}$ has been shown in Fig. 3. The third batch of simulations has been done for Cl-doped CdS/CZTS structure. During these simulations, the carrier concentration of $\mathrm{Cl}$-doped $\mathrm{CdS}$ has been changed from $3 \times 10^{18}$ to $9 \times 10^{19} \mathrm{~cm}^{-3}$, experimentally found by researchers [20].The variations of solar cell

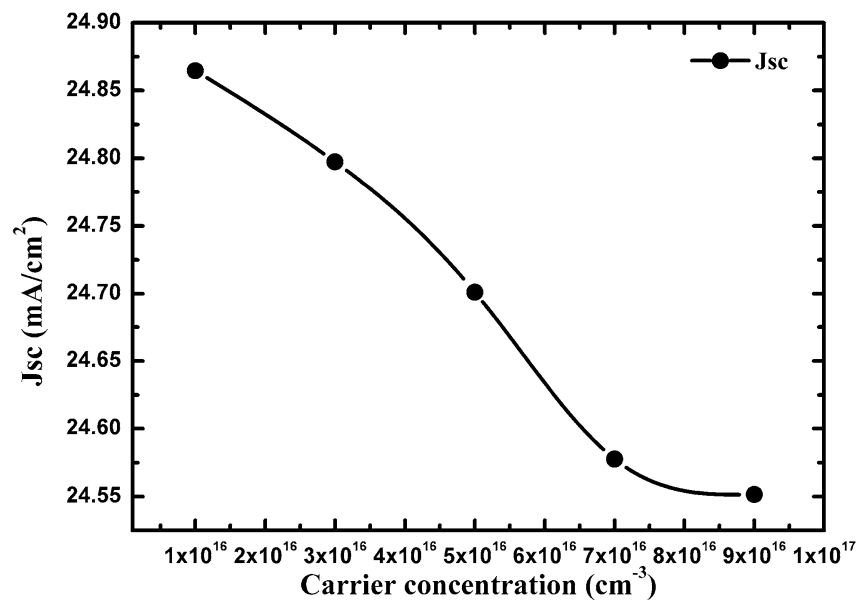

(b)

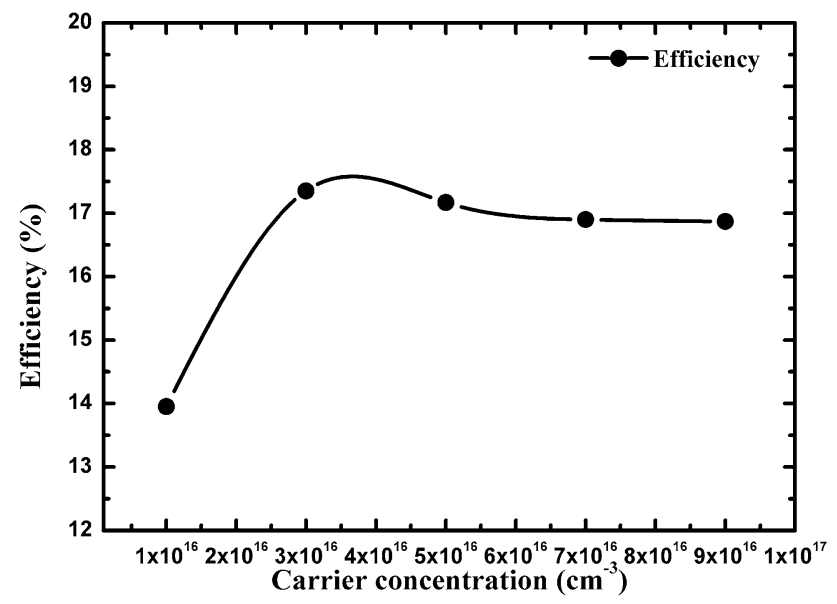

(d)

Fig. 3 Effect of carrier concentration of Cu-doped CdS layer on $\mathbf{a} V_{\mathrm{oc}}, \mathbf{b} J_{\mathrm{sc}}, \mathbf{c}$ fill factor, $\mathbf{d}$ efficiency 
parameters have been displayed in Fig. 4. During all these simulations, the thickness of three CdS-doped buffer layers was fixed at $50 \mathrm{~nm}$.

For Ag-doped $\mathrm{CdS}$, the lower concentration level results in higher barrier potential at CdS/CZTS heterojunction which leads to increase the $V_{\mathrm{oc}}$ [33]. The increasing trend of $V_{\text {oc }}$ is found for the studied Ag-doped CdS as shown in Fig. 2a. Similar kind of increasing trend has been found for $\mathrm{Cu}$-doped CdS up to carrier concentration of $3 \times 10^{16} \mathrm{~cm}^{-3}$ (Fig. 3a). Then, with an increase in carrier concentration, $V_{\text {oc }}$ shows a decreasing trend up to $5 \times 10^{16} \mathrm{~cm}^{-3}$, afterward it saturates for the studied range. It is likely due to the nonradiative recombination process which starts at buffer absorber interface. This recombination process increases the saturation current density resulting in a reduction in the value of $V_{\text {oc }}$ [33]. For Cl-doped CdS, no significant change has been found (Fig. 4a) which can be because of the fact that injection of new carrier at this concentration level cannot affect the solar cell performance that much. The value of $J_{\mathrm{sc}}$ has

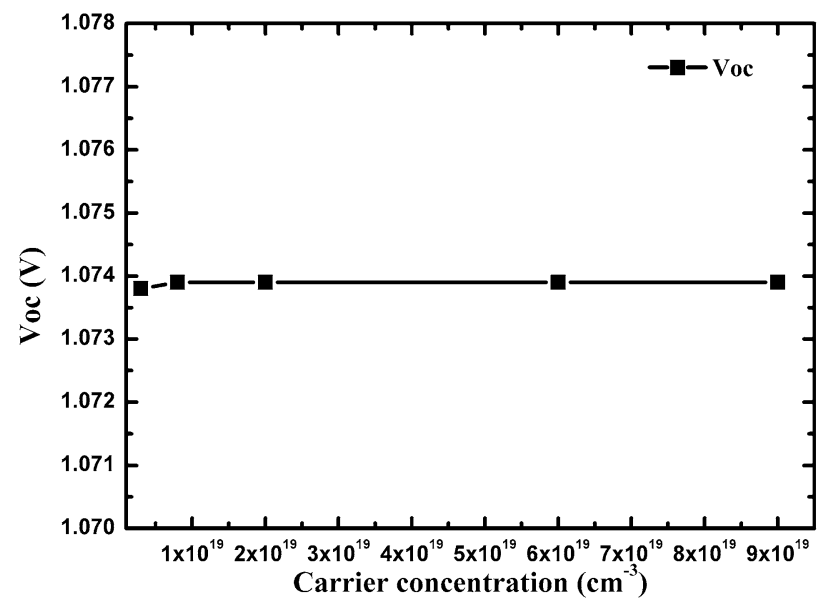

(a)

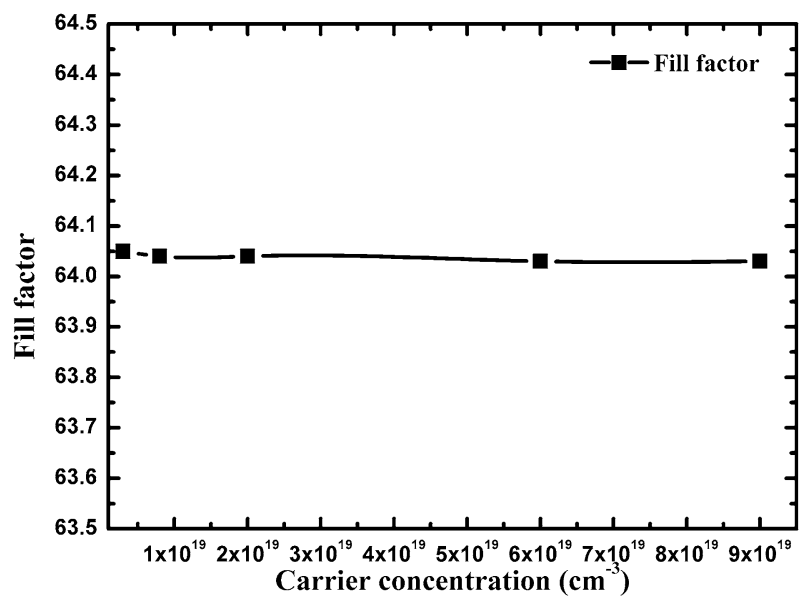

(c) decreasing trend for all three dopants of CdS displayed in Figs. $2 b, 3 b$ and $4 b$, respectively. Increasing carrier concentration results in decreased diffusion length of the charge carriers leading to lower value of $J_{\mathrm{sc}}$ [34].

The fill factor changes according to the open circuit voltage and the changes have been shown in Figs. 2c, 3c and 4c for Ag-doped, $\mathrm{Cu}$-doped and $\mathrm{Cl}$-doped $\mathrm{CdS}$, respectively. The conversion efficiency $\eta$ has lower value for Ag-doped $\mathrm{CdS}$ initially which increases with increasing carrier concentration. This is due to the decrement of barrier potential in buffer absorber heterojunction which leads to an increment of zone of space charge. This results in a good collection of photo-generated carriers which increases the conversion efficiency [35]. This type of increasing trend of efficiency has also been observed for $\mathrm{Cu}$-doped $\mathrm{CdS}$ up to $5 \times 10^{16} \mathrm{~cm}^{-3}$. But as the concentration increases, more recombination occur at the heterojunction resulting in the suppression of the efficiency of solar cell for $\mathrm{Cu}$-doped $\mathrm{CdS}$ [33]. The efficiency of Cl-doped CdS displayed in Fig. 4d

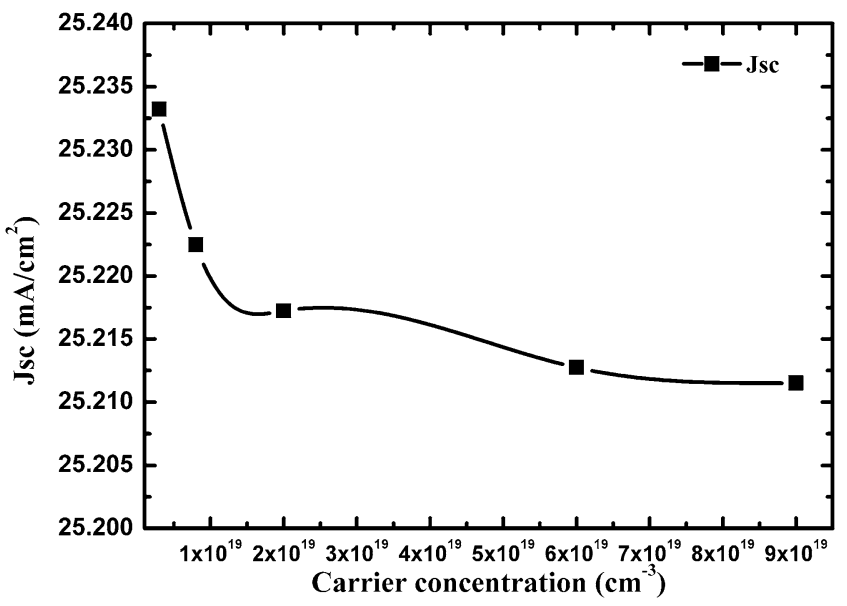

(b)

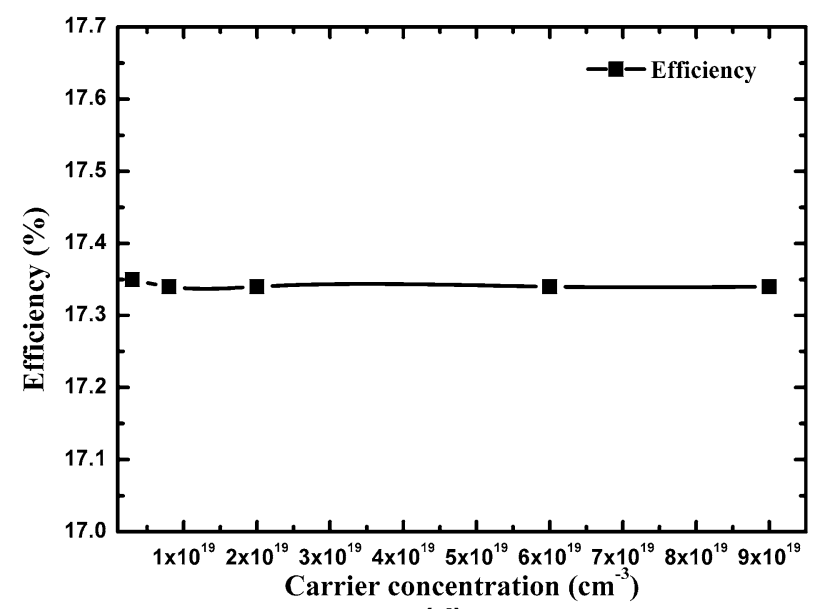

(d)

Fig. 4 Effect of carrier concentration of Cl-doped CdS layer on $\mathbf{a} V_{\mathrm{oc}}, \mathbf{b} J_{\mathrm{sc}}, \mathbf{c}$ fill factor, $\mathbf{d}$ efficiency 
Table 2 The optimized solar cell parameters for optimized carrier concentration of three doped buffer layer

\begin{tabular}{llllll}
\hline Name of layer & $\begin{array}{l}\text { Carrier } \\
\text { concentration } \\
\left(\mathrm{cm}^{-3}\right)\end{array}$ & $V_{\mathrm{oc}}(\mathrm{V})$ & $\mathrm{J}_{\mathrm{sc}}\left(\mathrm{mA} / \mathrm{cm}^{2}\right)$ & $\mathrm{FF}$ & $\eta(\%)$ \\
\hline $\begin{array}{l}\text { Ag-doped } \\
\text { CdS }\end{array}$ & $7 \times 10^{15}$ & 0.9207 & 25.584827 & 52.23 & 13.61 \\
$\begin{array}{l}\text { Cu-doped } \\
\text { CdS }\end{array}$ & $3 \times 10^{16}$ & 1.2091 & 24.797440 & 57.86 & 17.35 \\
$\begin{array}{l}\text { Cl-doped CdS } \\
\text { (15 }\end{array}$ & $3 \times 10^{18}$ & 1.0738 & 25.233207 & 64.05 & 17.35 \\
\hline
\end{tabular}

seems independent for the studied range. The optimized solar cell parameters for the three doped buffer layer are summarized in Table 2.

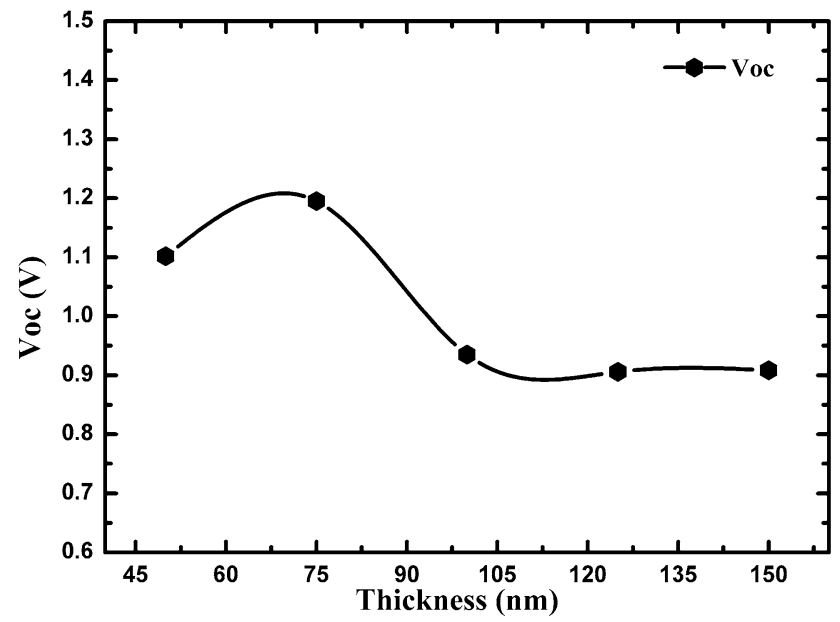

(a)

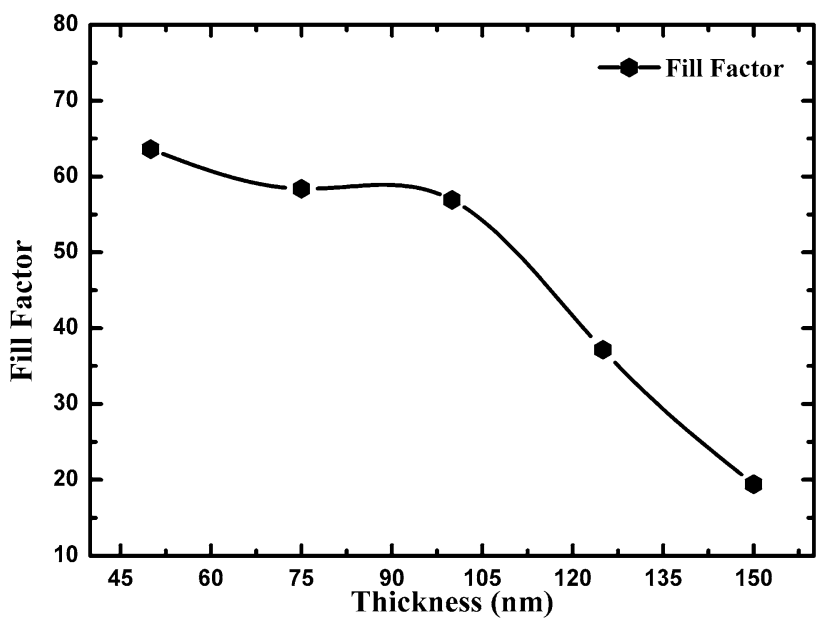

(c)

\section{Effect of doped CdS buffer thickness}

The effect of CdS buffer layer thickness using three dopants $\mathrm{Ag}, \mathrm{Cu}$ and $\mathrm{Cl}$ for the CZTS solar cell has been studied here. For each simulation, the doped CdS buffer thickness varied from 50 to $150 \mathrm{~nm}$ to find the suitable thickness of doped buffer layer. The carrier concentration of Ag-doped $\mathrm{CdS}, \mathrm{Cu}$-doped $\mathrm{CdS}$ and $\mathrm{Cl}$-doped $\mathrm{CdS}$ were fixed at $7 \times 10^{15} \mathrm{~cm}^{-3}, 3 \times 10^{16} \mathrm{~cm}^{-3}$ and $3 \times 10^{18} \mathrm{~cm}^{-3}$, respectively, optimized from the previous simulations. The variation of solar cell performance parameters with respect to the thickness of doped CdS buffer layer has been displayed in Figs. 5, 6 and 7, respectively, for Ag-doped CdS, Cu-doped CdS and Cl-doped CdS.

The open circuit voltage for Ag-doped and $\mathrm{Cu}$-doped CdS shows first increasing and then a decreasing behavior (Figs. 5a, 6a).However, this parameter has shown only decreasing nature for $\mathrm{Cl}$-doped $\mathrm{CdS}$ (Fig. 7a). The open

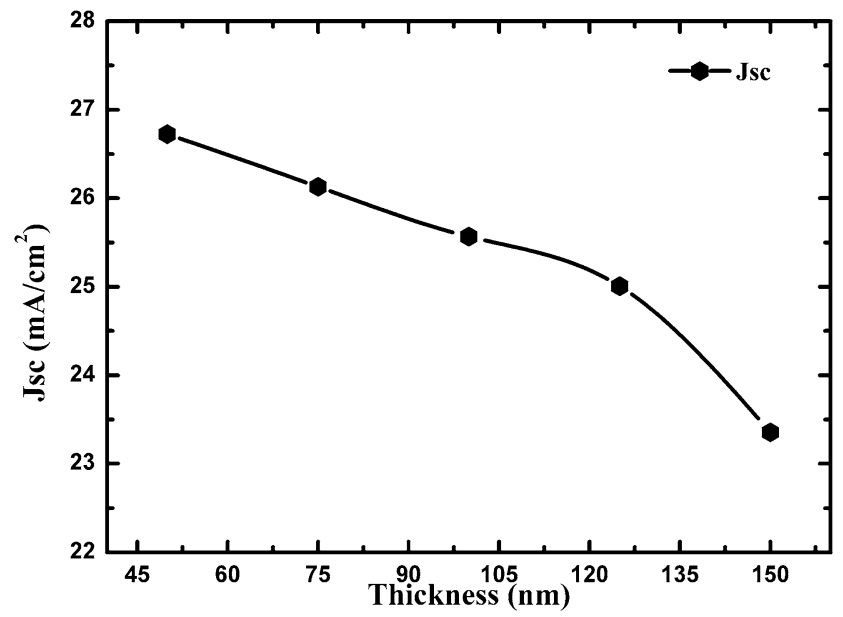

(b)

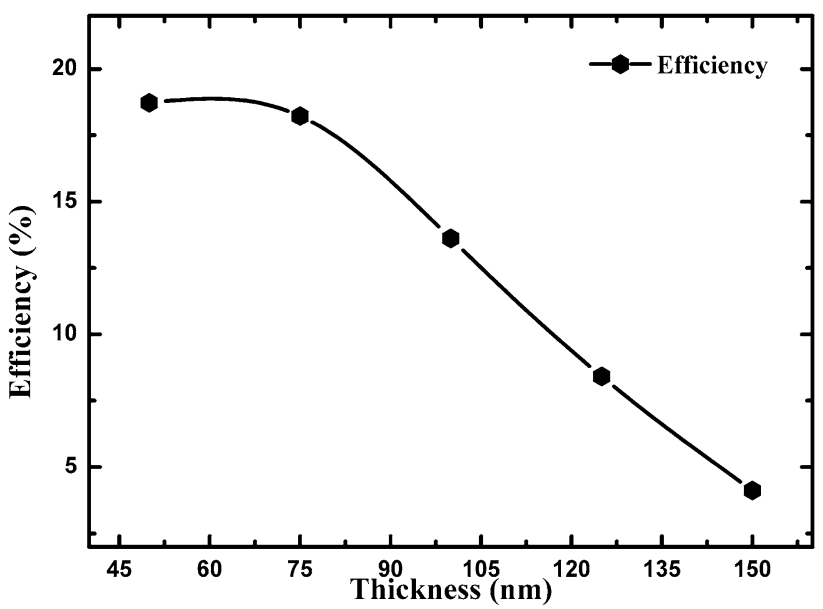

(d)

Fig. 5 Effect of thickness of Ag-doped CdS layer on $\mathbf{a} V_{\text {oc }}, \mathbf{b} J_{\text {sc }}$, $\mathbf{c}$ fill factor, $\mathbf{d}$ efficiency 


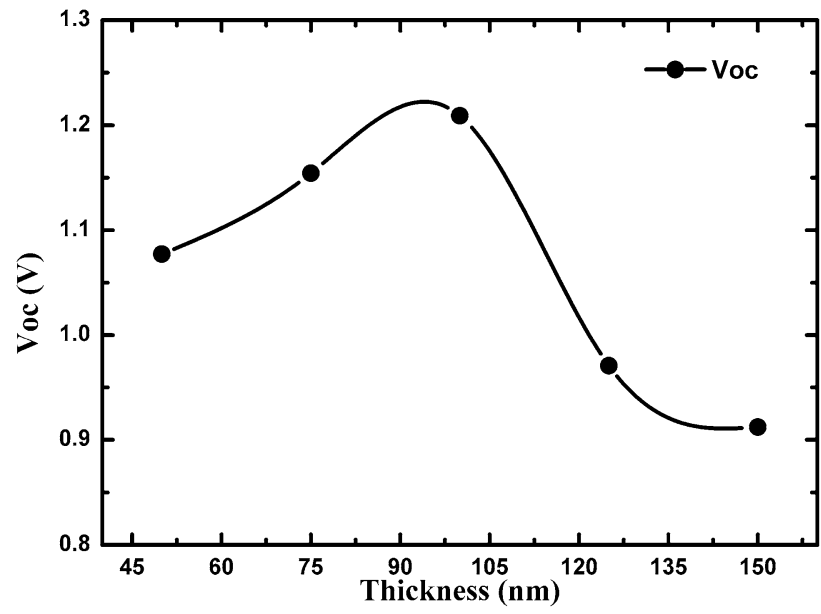

(a)

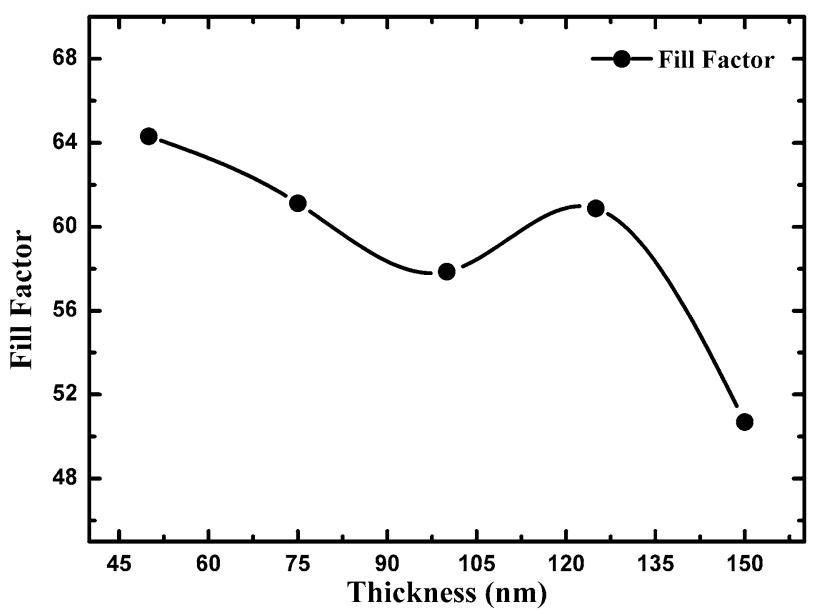

(c)

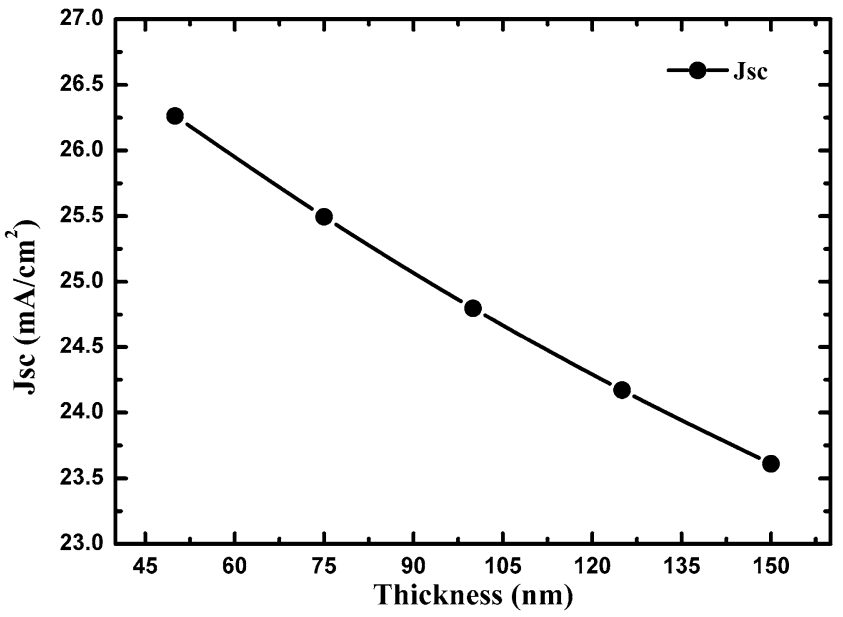

(b)

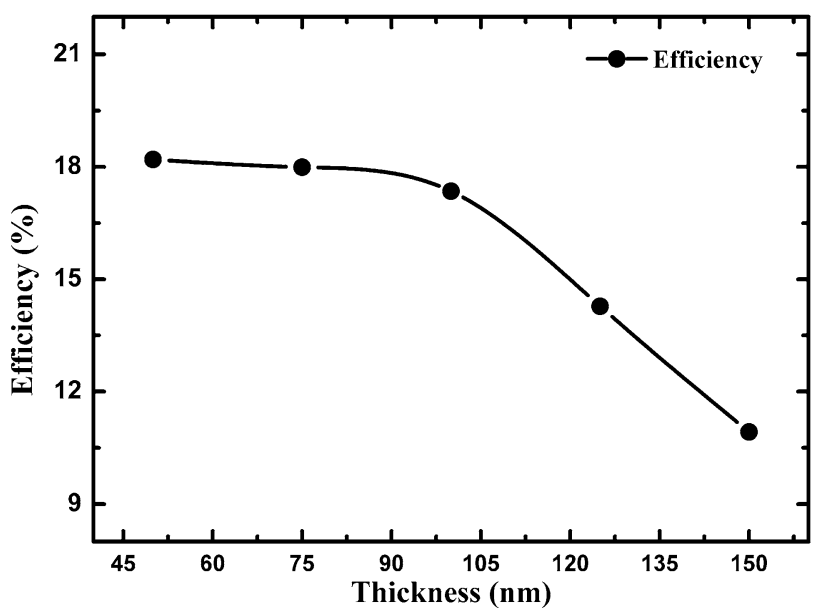

(d)

Fig. 6 Effect of thickness of Cu-doped CdS layer on $\mathbf{a} V_{\mathrm{oc}}, \mathbf{b} J_{\mathrm{sc}}, \mathbf{c}$ fill factor, $\mathbf{d}$ efficiency

circuit voltage increases with increasing buffer layer thickness due to the increasing amount of photon absorption outside the hole diffusion length lowering the recombination rate [36]. At the same time, $V_{\text {oc }}$ is also affected by the carrier concentration of the buffer which does not allow it to increase further and so it starts to decrease after certain thickness (after $75 \mathrm{~nm}$ for Ag-doped CdS and after $100 \mathrm{~nm}$ for $\mathrm{Cu}$-doped $\mathrm{CdS}$ ) [37]. For Cl-doped $\mathrm{CdS}$, the carrier concentration is so high that the recombination rate cannot affect the $V_{\mathrm{oc}}$ and so only decreasing nature can be observed for this structure shown in Fig. 7a.

The short circuit density for all structures decreases with increased buffer thickness shown in Figs. 5b, 6b and 7b. As buffer thickness increases, the production of electron hole pair deteriorates due to the less injection of incident photon in the absorber layer and for this reason the value of $J_{\mathrm{sc}}$ decreases [28].
Another parameter fill factor of solar cell is inversely dependent on $V_{\text {oc }}$ and $J_{\mathrm{sc}}$ [37]. For Cl-doped CdS, the fill factor is influenced by the open circuit voltage and short circuit current density. The decreasing nature of both quantity leads to increase the fill factor of the solar cell shown in Fig. 7c. But for Ag-doped and $\mathrm{Cu}$-doped $\mathrm{CdS}$, fill factor decreases with an increase in thickness displayed in Figs. 5c and 6c. For Ag-doped and $\mathrm{Cu}$-doped $\mathrm{CdS}$, fill factor decreases due to the increased series resistance increasing with thickness which reduces the maximum achievable power output [38].

Finally, alteration of efficiencies for $\mathrm{Ag}$-doped, $\mathrm{Cu}$-doped and $\mathrm{Cl}$-doped $\mathrm{CdS}$ are presented in Figs. 5d, 6d and 7d, respectively. For all three structures, the efficiency shows a decreasing trend. When the thickness of buffer layer increases, a great number of incident photons are absorbed in the buffer layer rather than the CZTS absorber layer. So the number of electron hole pair generation decreases and 


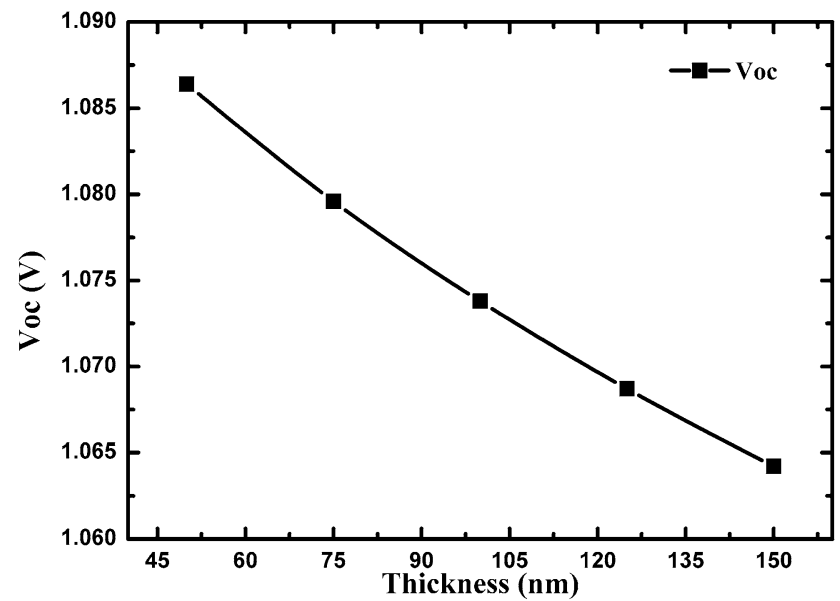

(a)

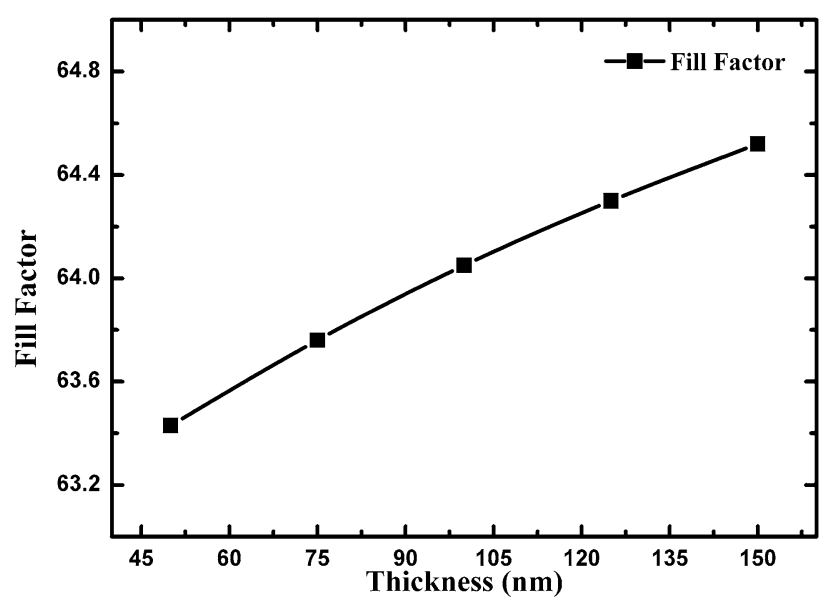

(c)

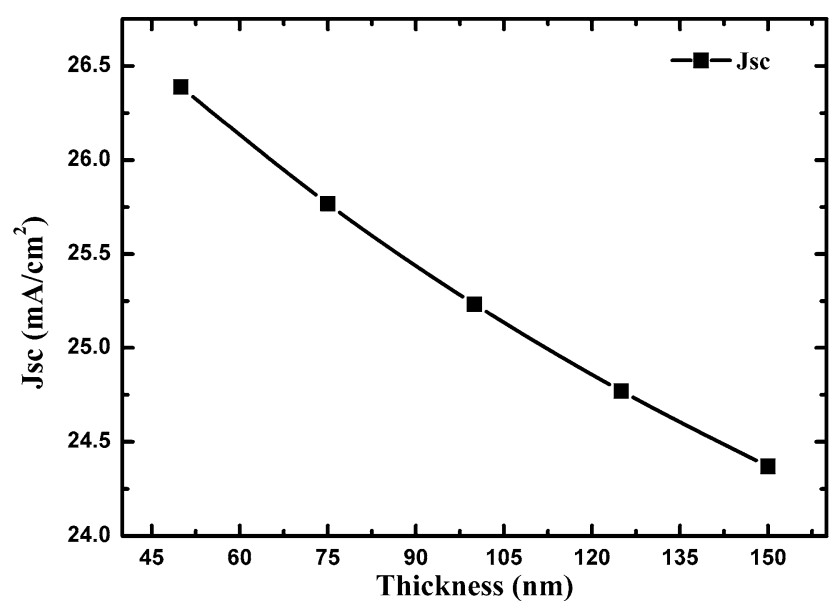

(b)

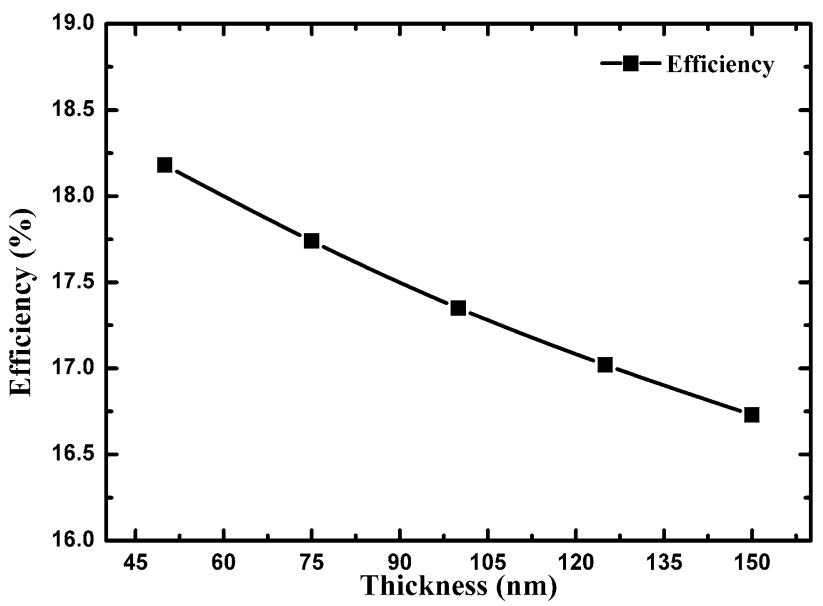

(d)

Fig. 7 Effect of thickness of Cl-doped CdS layer on $\mathbf{a} V_{\mathrm{oc}}, \mathbf{b} J_{\mathrm{sc}}, \mathbf{c}$ fill factor, $\mathbf{d}$ efficiency

thus worsens the efficiency of solar cell [28]. The efficiency can also be deteriorated by the additional trapping level introduced by defect [39]. The optimized values of solar cell parameters for three doped CdS buffer layer for these simulations have been summarized in Table 3 .

\section{Conclusion}

In this work, numerical simulations have been done on three different structures containing three different doped CdS buffer layer (doped with silver, copper and chlorine) to numerically analyze the performance of CZTS solar cell by varying the carrier concentration and then thickness of the doped buffer layer. The numerical studies have showed significant changes for Ag-doped and Cu-doped CdS with respect to $\mathrm{Cl}$-doped $\mathrm{CdS}$ for the variation of carrier concentration. The highest efficiency obtained for this simulation has been found $17.35 \%$ for both $\mathrm{Cu}$-doped and $\mathrm{Cl}$ doped CdS provided that the carrier concentration should be kept in between $10^{16}$ and $10^{18} \mathrm{~cm}^{-3}$. The study of thickness variation has indicated that the optimized thickness for each of the doped buffer layer should be around $50 \mathrm{~nm}$ to avoid the absorption of the incident photon in the buffer layer that can result in at higher thickness. The results direct

Table 3 The optimized solar cell parameters for optimized thickness of three doped buffer layer

\begin{tabular}{llllll}
\hline Name of layer & $\begin{array}{l}\text { Thick- } \\
\text { ness } \\
(\mathrm{nm})\end{array}$ & $V_{\mathrm{oc}}(\mathrm{V})$ & $J_{\mathrm{sc}}\left(\mathrm{mA} / \mathrm{cm}^{2}\right)$ & FF & $\eta(\%)$ \\
\hline Ag-doped CdS & 50 & 1.0864 & 26.388329 & 63.43 & 18.18 \\
Cu-doped CdS & 50 & 1.0773 & 26.263864 & 64.31 & 18.20 \\
Cl-doped CdS & 50 & 1.0864 & 26.388329 & 63.43 & 18.18 \\
\hline
\end{tabular}


the possibility to use doped CdS as an efficient buffer layer for high efficiency CZTS solar cell.

Open Access This article is licensed under a Creative Commons Attribution 4.0 International License, which permits use, sharing, adaptation, distribution and reproduction in any medium or format, as long as you give appropriate credit to the original author(s) and the source, provide a link to the Creative Commons licence, and indicate if changes were made. The images or other third party material in this article are included in the article's Creative Commons licence, unless indicated otherwise in a credit line to the material. If material is not included in the article's Creative Commons licence and your intended use is not permitted by statutory regulation or exceeds the permitted use, you will need to obtain permission directly from the copyright holder. To view a copy of this licence, visit http://creativecommons.org/licenses/by/4.0/.

\section{References}

1. Bagher, A.M., Vahid, M.M.A., Mohsen, M.: Types of solar cells and application. Am. J. Opt. Photonics 3(5), 94-113 (2015)

2. Rao, S., Morankar, A., Verma, H., Goswami, P.: Emerging photovoltaics: organic, copper zinc tin sulphide and perovskite-based solar cells. J. Appl. Chem. 2016, 1-12 (2016)

3. Swami, R.: Solar cell. Int. J. Sci. Res. Publ. 2(7), 1-5 (2012)

4. Zhao, J., Wang, A., Green, M.A.: 24.5\% Efficiency silicon PERT cells on MCZ substrates and 24.7\% efficiency PERL cells on FZ substrates. Prog. Photovolt. Res. Appl. 7(6), 471-474 (1999)

5. Kaur, M., Singh, H.: A review: comparison of silicon solar cells and thin film solar cells. Int. J. Core Eng. Manag. (IJCEM) 3(2), 15-23 (2016)

6. Green, M.A., Emery, K., Hisikawa, Y., Warta, W., Dunlop, E.D.: Solar cell efficiency tables (version 50). Prog. Photovolt. Res. Appl. 2018(26), 3-12 (2018)

7. Yeh, M.Y., Lei, P.H., Lin, S.H., Yang, C.D.: Copper-zinc-tin-sulfur thin film using spin-coating technology. Materials 9(7), 526 (2016)

8. Katagiri, H., Jimbo, K., Maw, W.S., Takeuchi, A.: Development of CZTS based thin film solar cells. Thin Solid Films 517(7), 2455-2460 (2009)

9. Hironori, K., Kotoe, S., Tsukasa, W., Hiroyuki, S., Tomomi, K., Shinsuke, M.: Development of thin film solar cell based On $\mathrm{Cu}_{2} \mathrm{ZnSnS}_{4}$ thin films. Sol. Energy Mater. Sol. Cells 65(1-4), 141-148 (2001)

10. Zakaria, Z., Chelvanathan, P., Rashid, M.J., Akhtaruzzaman, M., Alam, M.M., Al-Othman, Z.A., Alamoud, A., Sopian, K., Amin, N.: Effects of sulfurization temperature on $\mathrm{Cu}_{2} \mathrm{ZnSnS}_{4}$ thin film deposited by single source thermal evaporation method. Jpn. J. Appl. Phys. 54, 1-5 (2015)

11. Yan, C., Huang, J., Sun, K., Johnston, S., Zhang, Y., Sun, H., Pu, A., He, M., Liu, F., Eder, K., Yang, L., Cairney, J.M., EkinsDaukes, N.J., Hameiri, Z., Stride, J.A., Chen, S., Green, M.A., $\mathrm{Ha}, \mathrm{X} .: \mathrm{Cu}_{2} \mathrm{ZnSnS}_{4}$ solar cells with over $10 \%$ power conversion efficiency enabled by heterojunction heat treatment. Nat Energy 3(9), 764 (2018)

12. Jhuma, F.A., Shaily, M.Z., Rashid, M.J.: Towards high efficiency CZTS solar cell through buffer layer optimization. Mater. Renew. Sustain. Energy 8(6), 1-7 (2019)

13. Cantas, A., Turkoglu, F., Meric, E., Akca, F.G., Ozdemir, M., Tarhan, E., Ozyuzer, L., Aygun, G.: Importance of CdS buffer layer thickness on $\mathrm{Cu}_{2} \mathrm{ZnSnS}_{4}$ based solar cell efficiency. J. Phys. D Appl. Phys. 51(27), 1-33 (2018)
14. Pandya, S.G.: Preparation and characterization of cadmium sulphide nanocrystalline thin film grown by chemical method. Int. J. Recent Sci. Res. 7(12), 14887-14890 (2016)

15. Ghosh, P.K.: Effect of particle size on dielectric properties of CdS nano-particles. Int. J. Hybrid Inf. Technol. 8(4), 49-54 (2015)

16. Suresh, S.: Studies on the dielectric properties of CdS nanoparticles. Appl. Nanosci. 4(3), 325-329 (2014)

17. Faraj, M.G., Ibrahim, K.: Comparison of cadmium sulfide thin films deposited on glass and polyethylene terephthalate substrates with thermal evaporation for solar cell applications. J. Mater. Sci. Mater. Electron. 23(6), 1219-1223 (2012)

18. Singh, B., Singh, J., Kaur, R., Moudgil, R.K., Tripathi, S.K.: Quantitative measurement of transport properties: Ag-doped nanocrystalline CdS thin films. R. Soc. Chem. 7, 53951-53962 (2017)

19. Brandhorst, H.W.: Impurity profile and energy band diagram for the cuprous sulfide-cadmium sulfide heterojunction. National Aeronautics and Space Administration, Washington (1969)

20. Safe, H.H.A., Hossain, M., Naseem, H., Brown, W., Dhafiri, A.A.: Chlorine-doped $\mathrm{CdS}$ thin films from $\mathrm{CdCl}_{2}$-mixed $\mathrm{CdS}$ powder. J. Electron. Mater. 33(2), 128-134 (2004)

21. Islam, M.A., Hossain, M.S., Aliyu, M.M., Yusuf Sulaiman, T., Razykov, K., Sopian, N.Amin: Structural, optical and electrical properties of in doped CdS thin films prepared from cosputtering technique. J. Ovonic Res. 10(5), 185-190 (2014)

22. Patil, B.N., Naik, D.B., Shrivastava, V.S.: Synthesis and characterization of $\mathrm{Al}$ doped $\mathrm{CdS}$ thin films grown by chemical bath deposition method and its application to remove dye by photocatalytic treatment. Chalcogenide Lett. 8(2), 117-121 (2011)

23. Yang, K.J., Sim, J.H., Jeon, B., Son, D.H., Kim, D.H., Sung, S.J., Hwang, D.K., Song, S., Khadka, D.B., Kim, J., Kang, J.K.: Effects of $\mathrm{Na}$ and $\mathrm{MoS}_{2}$ on $\mathrm{Cu}_{2} \mathrm{ZnSnS}_{4}$ thin-film solar cell. Prog. Photovolt. Res. Appl. 23(7), 862-873 (2014)

24. Fuhs, W.: Zinc oxide-a material for micro- and optoelectronic applications. NATO Sci. Ser. II Math. Phys. Chem. 194, 197-209 (2005)

25. Coutts, T.J., Mason, T.O., Perkins, J.D., Ginley, D.S.: Transparent conducting oxides: status and opportunities in basic research. Electrochem. Soc. Proc. 99-11, 274-289 (1999)

26. Niemegeers, A., Burgelman, M., Decock, K., Verschraegen, J., Degrave, S.: SCAPS manual, Version: 19, December 2016, http:// scaps.elis.ugent.be/. Accessed 13 Apr 2019

27. Ferdaous, M.T., Islam, M.F., Haque, K.A.S.M.E., Amin, N.: Numerical analysis of ultra-thin high efficiency Cd1-xZnxS/ Cd1-xZnxTe solar cell. Electr. Electron. Eng. 2015(5(A)), 14-18 (2015)

28. Peijie, L., Lingyan, L., Jinling, Y., Shuying, C., Peimin, L., Qiao, $\mathrm{Z}$.: Numerical simulation of $\mathrm{Cu}_{2} \mathrm{ZnSnS}_{4}$ based solar cells with $\mathrm{In}_{2} \mathrm{~S}_{3}$ buffer layers by SCAPS-1D. J. Appl. Sci. Eng. 17(4), 383390 (2014)

29. Mebarkia, C., Dib, D., Zerfaoui, H., Belghit, R.: Energy efficiency of a photovoltaic cell based thin films CZTS by SCAPS. J. Fundam. Appl. Sci. 8(2), 363-371 (2016)

30. Wanda, M.D., Ouédraogo, S., Tchoffo, F., Zougmoré, F., Ndjaka, J.M.B.: Numerical investigations and analysis of $\mathrm{Cu}_{2} \mathrm{ZnSnS}_{4}$ based solar cells by SCAPS-1D. Int. J. Photoenergy 2016, 1-9 (2016)

31. Xie, R., Li, J.S.M., Guo, L.: Structural and photo electrochemical properties of $\mathrm{Cu}$-doped $\mathrm{CdS}$ thin films prepared by ultrasonic spray pyrolysis. Int. J. Photoenergy 2013, 1-7 (2013)

32. Sivaraman, T., Narasimman, V., Nagarethinam, V.S., Balu, A.R.: Effect of chlorine doping on the structural, morphological, optical and electrical properties of spray deposited CdS thin films. Prog. Nat. Sci. Mater. Int. 25(5), 392-398 (2015)

33. Kanevce, A., Reese, M.O., Barnes, T.M., Jensen, S.A., Metzger, W.K.: The roles of carrier concentration and interface, bulk, 
and grain-boundary recombination for $25 \%$ efficient CdTe solar cells. J. Appl. Phys. 121(21), 214506 (2017)

34. Kolsi, S., Ben Amar, M., Samet, H., Ouali, A.: Effect of Gaussian doping profile on the performance of a thin film polycrystalline solar cell. EPJ Web Conf. 29, 1-11 (2012)

35. Dabbabi, S., Nasr, T.B., Turki, N.K.: Parameters optimization of CIGS solar cell using 2D physical modeling. Results Phys. 7, 4020-4024 (2017)

36. Green, M.A.: Solar cells: operating principles, technologies and system applications, pp. 86-88. Prentice Hall, Eaglewood Cliffs (1982)

37. Mauk, M., Sims, P., Rand, J., Barnett, A.: Solar cells: materials, manufacture and operation, pp. 115-156. Academic Press, Cambridge (2013)
38. Dadu, M., Kapoor, A., Tripathi, K.N.: Effect of operating current dependent series resistance on the fill factor of a solar cell. Sol. Energy Mater. Sol. Cells 71(2), 213-218 (2002)

39. Huang, J.Y., Lin, C.Y., Shen, C.H., Shieh, J.M., Da, B.T.: Low cost high-efficiency amorphous silicon solar cells with improved light-soaking stability. Sol. Energy Mater. Sol. Cells 98, 277-282 (2012)

Publisher's Note Springer Nature remains neutral with regard to jurisdictional claims in published maps and institutional affiliations. 